\title{
Global Context of the Polish-Chinese Relations
}

\author{
Wojciech Zajączkowski
}

Thanks to the reforms initiated in late 1970s, China was able to join in and benefit from the subsequent waves of globalization. Decades of rapid economic growth made it possible to increase China's role in the world economy and international relations in a relatively short period of time. Its impact on, by now essentially all other countries, is multidimensional and stems not only from the sheer size of the Chinese economy and related trade links, but ever more from qualitative factors like its technological sophistication and zeal for innovation. In this article, I would like to share some thoughts and observations on the role China plays in globalization, international trade and fighting climate change. I will do so from the Polish perspective.

\section{Globalization, Trade and Climate}

China's growing economic and political importance can be observed using different indicators, but an overall assessment would probably stress the vital role played by China in globalization. With its crucial position in international production chains, China has vastly expanded trade relations and put itself in central position in world transport links. Foreign investment expansion, combined with growing presence in financial markets, has allowed many Chinese enterprises to build their presence on all continents and become part of everyday life of many. As China aims to become a global centre for innovation and technology, its perception in many parts of the world is already as that of a developed country.

With its ambitious Belt and Road Initiative, China has also started to seriously reflect on infrastructure needs worldwide. Such boldness, supported by the abovementioned processes and achievements, has unsurprisingly created high expectations in many countries. However, global needs far exceed what one country, even China,

W. Zajączkowski $(\bowtie)$

Embassy of the Republic of Poland to the People's Republic of China, Beijing, China 
can achieve on its own. What is needed, whether in bilateral or multilateral cooperation, is mutual trust built upon sustainability and predictability. As lower than expected returns can create hurdles not only in the realization of particular projects, an overall atmosphere of cooperation is essential to take into consideration interests of wide variety of stakeholders.

Cooperation on climate protection is one of the fields in which the international community simply cannot risk failure, as the challenges brought with the deterioration of natural environment affect every country, and cause significant damage. At the same time, to achieve success we need to build a strong international framework to overcome the economic and political constraints that currently put limits on actions of single countries. Related issues are of a complex nature, and therefore need a set of solutions, and what seems equally important are ways to verify this progress.

China, as the world's largest emitter of greenhouse gases, is an essential partner in any meaningful action to mitigate the impact of climate change. We have already seen big investments in this regard on the Chinese side, and commitments such as the declaration of carbon neutrality by 2060 , which further demonstrate the will of the leadership of China. Moreover, being a leader in green technologies and renewable energy, China could also support other countries efforts in improving their situation. This can be a good foundation for successful multilateral efforts, provided we manage our cooperation in a way that keeps all participants in.

\section{COVID-19}

The COVID-19 pandemic has reminded us of our vulnerabilities and pressed for re-evaluation of risks we face in different areas, including international economic relations. Since the pandemic is still taking its toll around most of the world, and governments are still mostly focused on the public health dimension, it is too early to draw final conclusions and recommendations for the future. Nevertheless, some preliminary observations based mostly on the developments during the early phase of the pandemic are already quite clear. Most important, not everything worked ideally in 2020 .

The speed and scale of the spread of this then largely unknown disease made many governments draw back not only from multilateral methods, but even from bilateral ones, as decisions began to be made unilaterally and often in an uncoordinated way. Limitations on international travel, particularly flight cancellations, have frozen a significant part of international exchange. The resulting paralysis of transport networks only added difficulty to the scarcity of medical protection materials. With time, some challenges have been addressed, but many issues still remain to be solved.

The unprecedented speed of the development of vaccines against COVID-19 brought hope, while at the same time also once again drawing our attention to production and distribution challenges that were faced regarding protective gear. The future of the virus itself, especially characteristics of its mutations, mean that disruptions might be unavoidable. This, added to the differences among nations in implementing 
vaccination programmes, means that global economic recovery is likely to be slower than expected and might enhance regional economic integration rather than recovery at a global level.

China appears to have recovered quicker than other countries, mostly thanks to rapid elimination of the public health risks related to the spread of the virus itself. Since we need connectivity for trade and investment, at one point the world might need a thorough re-evaluation of risks faced with direct people-to-people contact, as opposed to the need of economic development. Effective and widely used vaccines would help governments in making this difficult assessment. While the pandemic has strained multilateralism, international coordination looks inevitable.

\section{Poland-China Relations}

Poland is open to cooperation with China in all of the above-mentioned areas, as our role in international efforts for global economic recovery requires us to engage China as well. While the spread of COVID-19 has, because of travel restrictions and social distancing rules, greatly impacted the normal conduct of international relations, in my opinion Poland and China have been successful in overcoming this negative impact as we have managed to continue intensive political and economic contacts. Poland's President Andrzej Duda had phone conversations with President Xi Jinping, while Prime Minister Mateusz Morawiecki spoke with Prime Minister Li Keqiang. Ministers of Foreign Affairs held phone conversations as well. In 2020, China was one of the largest sources of medical equipment and protective gear for us. While Poland perceives bilateral relations with China and the EU-China relations as a priority, " $17+1$ " is part of our broad cooperation agenda with China. The organization of the Beijing summit in February 2021 confirmed that COVID-19 pandemic did not stop us from seeking ways of pragmatic cooperation.

The global pandemic has required us all to intensively explore ways of supporting economic recovery, and multilateral cooperation is definitely one of the areas that has great potential. Poland actively participated in preparations for the China-EU Comprehensive Agreement on Investment (CAI), as well as the Strategic Agenda for Cooperation 2025. This shows the vast spectrum of opportunities Poland, together with other EU countries, present to China and simultaneously share with China. With this in mind, there are a number of areas Poland and China can enhance cooperation, ranging from logistics to green technologies.

Taking a broader approach, it has to be noted first that while in the period after the transformation in 1989, and before entering the EU in 2004, we had been more focused on domestic issues, but over the past ten years, Poland has come back to East Asia. One of the symbols of this process was the establishment of a strategic partnership with China in 2011, which was further elevated to the status of a comprehensive strategic partnership in 2016. With this, we have seen a steady development of pragmatic and result-oriented Polish-Chinese cooperation in a number of areas. 
These range from trade and economy, science and education, to culture and peopleto-people exchanges. Nowadays, we are interconnected with China in many different ways, with industrial production chains stretching from East Asia to Europe; therefore, we should closely work on creating an economic environment that would bring sustainable growth to all interested parties.

One of the most promising areas of cooperation from the Polish point of view is in connectivity. At the time of writing $85-90 \%$ of containers transported by rail from China to the EU passed through Malaszewicze on the Poland-Belarus border (the external border of the EU) and in 2020, we saw a significant rise of the number of containers, from 97,000 in 2019 to 155,000 in 2020 . We regard this very positively. Since major European transport corridors intersect in Poland, both on the EastWest and North-South axis, we already possess a strong position in the European transportation and logistics sector. From this perspective, transporting goods from China to Europe, and from Europe to China, can increase our competitiveness. This could be done not only by cargo trains, but also by maritime transport-the Baltic Sea's second-largest container port in Gdańsk already has direct lines to Chinese ports, or by air transport to Polish airports. In our opinion, we should seek synergies with networks beyond Europe and its neighbourhood. Having this in mind, Poland is willing to work with China on enhancing connectivity between Europe and Asia.

At this point, probably the biggest change rests in mindsets. For several centuries, maritime transportation has been the dominant method of transporting goods from Europe to Asia. Train connections, like the one from Chengdu to Lodz, have proven that overland connections between Europe and Asia are not only technically possible, but that there are also customers looking for such services. But to make full use of their potential requires exploring different business opportunities, as well as upgrading existing railway and logistics infrastructure.

With the growing popularity of China-Europe trains, the Polish government has already made significant investments in railway infrastructure in the Malaszewicze area, and preparation for further development is already very advanced as well. The same can be said about other places like Slawkow, which has the largest rail cargo terminal in the EU that uses broad-gauge railway lines (as used in Russia, Belarus and Kazakhstan), reducing the time normally needed to change to a different gauge. All of this is funded by the Polish state and companies and in some cases supported with the EU funds. At this point, we have not observed significant Chinese investments directly related to rail connections, but we could see the first signs of interest from Chinese companies related to logistics. We welcome this and encourage Chinese partners to take a closer look at Poland not only in terms of bilateral trade and investment but also with broader considerations, in which Poland could be a base for economic activities on a much wider, European scale.

But to fully leverage the potential of the above-mentioned rail connections, we should make them sustainable in the long term, and Poland should not only be the first stop for trains connecting China with Europe, but also the last stop for trains on their way to China carrying European, including Polish, goods to China. In this way, 
China-Europe trains can fully supplement air and sea cargo, as a reliable and costeffective means of transport. President Andrzej Duda and President Xi Jinping have been correct in attaching high value to connectivity, which is evident in his assessment expressed during the " $17+1$ " summit that the development of the China-Europe Railway Express is needed to unlock the full potential of our cooperation.

Since early 2020, the world has been occupied with the COVID-19 pandemic. While this public health crisis has on its own brought challenges unseen for decades, it also made more visible, and in some cases accelerated trends that have already been developing for some time. A reverse in globalization and bottlenecks in international trade, both marked by a trend of greater self-reliance in some countries, as well as pressing needs coming from the climate change, are profound examples of such processes. They also demonstrate the need for upholding a rules-based multilateral system to deal effectively with global problems. To address all of the aforementioned challenges, the world needs China, just as much as China needs the world. This seems especially poignant when thinking about the economic recovery from the pandemic and the post-pandemic world order.

The threat of COVID-19 made governments all over the world unilaterally impose various measures aimed at protecting the life and health of their citizens. However, while helping to overcome the public health crisis, these measures had a negative impact on domestic economic growth, as well as international economic cooperation. Fortunately, with time we gained more understanding of the situation and could adjust some of the policies accordingly. What is crucial, though, is that we should ensure that the economic recovery will be both fast and based on long-lasting foundations; otherwise, the benefits will only be short-lived and could even bring more difficulties in the future.

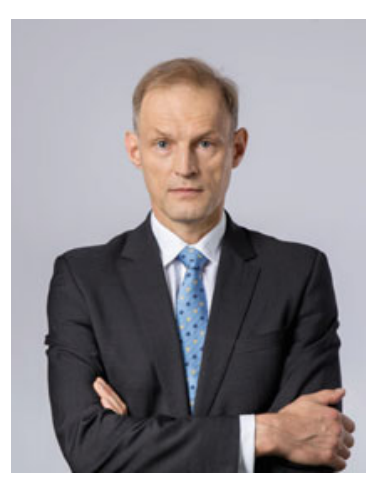

H.E. Mr. Wojciech Zajączkowski is the ambassador of the Republic of Poland to the People's Republic of China. He (b. 1963) is a Polish diplomat and since January 2018 has served as the ambassador of Poland to China. He graduated with a degree in history from the Catholic University of Lublin (1987), and received a PhD in political science at the Institute of Political Studies of the Polish Academy of Sciences (1999). After joining Polish Ministry of Foreign Affairs, he worked in multiple posts, including head of the Department of Eastern Policy (2004-2007) and the Department of Foreign Policy Strategy (2014-2018). He has also served as ambassador to Romania (2008-2010) and Russia (2010-2014). 
Open Access This chapter is licensed under the terms of the Creative Commons AttributionNonCommercial-NoDerivatives 4.0 International License (http://creativecommons.org/licenses/bync-nd/4.0/), which permits any noncommercial use, sharing, distribution and reproduction in any medium or format, as long as you give appropriate credit to the original author(s) and the source, provide a link to the Creative Commons license and indicate if you modified the licensed material. You do not have permission under this license to share adapted material derived from this chapter or parts of it.

The images or other third party material in this chapter are included in the chapter's Creative Commons license, unless indicated otherwise in a credit line to the material. If material is not included in the chapter's Creative Commons license and your intended use is not permitted by statutory regulation or exceeds the permitted use, you will need to obtain permission directly from the copyright holder.

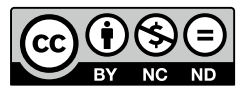

